\title{
Remembering War in Imperial Canada: David Ross McCord and The McCord National Museum
}

\author{
by Donald A. Wright
}

David Ross McCord. (1844-1930) was a man obsessed. Between the 1880 s and 1920 the drive to buila a national museum constituted an all-consuming obsession. The end result of his efforts is today the internationally renowned McCord Museun of Canadian History/Le Musée McCord d'hisioire canadienne. Although he amassed a collection of considerable breadth and depth, this paper focuses on one aspect of his collection: objects relating to the history of war. An ardent imperialist, McCord believed that war served a noble function in that it strengthened both individual manliness and national character. Early museum displays likewise emphasized war as a heroic and gallant affair and adhered very closely to what John Keegan terms the rhetoric of battle history. More significanily, David Ross McCord and the McCord National Museum perpetuated the Myth of the War Experience: to die for one's country is noble and right.

Hanté, David Ross McCord̉ (1844-1930) t'érait cenainement. Entre les années 1880 ê 1920, la volonié d'écifîer un musée national devient pour hui une obsession qui consume tout son temps. Ses efforts aboutissent à la création du Musée McCord d'histoire canadienne (McCord Museum of History), dont la renommée mondiale n'est plus à faire. Même si McCord a consitué une collection d'une ampleur considérable, cet article ne s'iniéresse qu'aux objets se rapportant à l'histoire de la guerre. Fervent impérialisie, McCord croyait que la guerre servait une fonction très noble puisqu'elle forgeait la virilité individuelle el le caractère de la nation. Les premières expositions du Musée donnaient d'ailleurs de la guerre une image à la fois héroüque et galante, conforme à ce que John Keegan qualifie de rhétorique de l'histoire de la bataille. David Ross McCord et le McCord National Museum ont d'ailleurs perpétué le mythe de la guerre: mourir pour sa parrie est à la fois noble et juste.

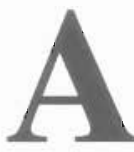

ttended by nembers of the peerage, prominent politicians and prestigious alumni, McGill University's centenary celebrations of 13 October 1921 were a fantastic affair, replete with much pomp and even more circumstance. "Brilliant was the scene in assembly hall at the Royal Victoria College yesterday afternoon," declared the Montreal Gazette, "when two hundred delegates" gathered "to start in procession for St. James Methodist Church" where a special convocation was to take placc. "Gowns of solemn black and royal purple alternated with robes of brilliant scarlet, quieter pink and spotless white. " Apart from this event, there was Lord Byng of Vimy's unveiling of a memorial tablet in the Arts Building dedicated to the McGill men killed in the Great War. There was also the announcement of a Graduate Endowment Fund designed to provide McGill with an annual income. Still part of the centenary was the formal transfer of the McCord National Museum to McGill. University. After ten years of protracted negotiations between David Ross McCord and his alma mater, ${ }^{2}$ and after ten months of moving the mammoth collection from Temple Grove to Joseph House, ${ }^{3}$ the McCord National Museum found its first permanent home on the comer of Sherbrooke and McTavish. Owing to his failing health, McCord himself could not attend the ceremony. ${ }^{4}$ In his place stood William Douw Lighthall, a close personal friend and well known citizen of Montreal. ${ }^{5}$ Addressing an intimate group of invited guests, Lighthall spoke briefly about the purpose of the museum in general, and this museum in particular.

Concerning the nature of such Museums. Many people cannot understand their value off-hand. But while it is true that there do exist collections accumulated without reasonable or serious object, this one is not such; but is intended to consist of pictures and articles properly illustrating Canadian history-or otherwise stimulating the imagination concerning it. The question of what rightly falls under these heads is too wide for discussion here; but the historical 
studen gifted with imagination will we believe recognize here at least the foundation of a well-conducted historical museum estabiished on lines of intelligent selection. ${ }^{6}$

The purpose of a museum is to record history: the purpose of the McCord National Museum is to record Canadian history.

In the absence of any criticisin of what MicCord had collected, there existed an unspoken but shared assumption as to what constituted Canadian history and how it should be recorded. Today, not only is consensus between museums and the public difficult to achieve, but conflict remains a very real possibility, especially when museums attempt io challenge the comforting myths and familiar narratives that constitute national memory, in particular the memory of war. The Smithsonian's National Air and Space Museum recently found itself at the centre of a controversy of national proportions: at issue was the proposed exhibit of the Enola Gay and the dropping of the atomic boinb on Hiroshima. "How should ine "last act' of World War II be recalled and presented to the public?" asked the American cultural historian Michael Kammen.

As a celebration of the valor of American military personnel who risked their lives in the name of freedom and followed orders from the commander-in-chief to prcvent the loss of unknown numbers of Americans? Or, should the use of atomic weapons on large urban sites and civilians be presented in inrms of a moral calamity with a complex legacy that suspended the world for decades in what W.H. Auden designated an 'Age of Anxiety'?

Ahough noi associated with a museum, two Canadian fiim-rnakers, Brian and Terence McKenna were in 1992 the similar targets of condemnation. Veterans groups charged the three-part television series The Valour and the Horror with willful distortion and anti-veteran bias, while the Senate Sub-Committee on Veterans Affairs investigated, among other things, the film's "historical methodology and merit." 8

The purpose of this paper, then, is to revisit one collector (David Ross McCord, 1844-1930) and one aspect of his collection (objects relating to military history) in an effort to study the construction of national war narratives which George Mosse calls the Myth of the War Experience, and are essential to "constructing a myth which would draw the sting from death in war and emphasize the meaningfulness of the fighting and sacrifice."

I

Why McCord began to collect is not clear. What is clear, however, is that from the mid-1880s to ahout 1920, his collecting amounted to a compulsive obsession, consuming all of his time and energy, and most of his money. ${ }^{10}$ it is aiso clear that at the cultural icvel, the fascination with the past constituted part of the Victorian response to modernity, to industrialization, urbanization, anonymity, detachment from the social and economic processes that impacted their lives, to "the break with the past in the form of a continual renewal." "Irasping for fixity in an age of relentless change, Victorian England experienced a flowering of museums while history emerged as a scholarly discipline, enjoying authority and prestige. "The Victorians' fascination with the past, " writes P.J. Bowler, "was thus the product of an age obsessed with change, desperately hoping that history itself might supply the reassurance that could no longer be derived from ancient beliefs." ${ }^{12}$ As a member of an élite Montreal farnily, and an imperialist, McCord was very much steeped in Victoriar. culture. Although he certainly believed in material progress, and although he celebrated technological achievements, he remained nevertheless ill at ease with modernity. Indeed, writing in the early 1890s, McCord worried about the "obliterating" forward march of time and the relentless advance of civilization. ${ }^{13}$ A few years later he questioned what he perceived to be the misguided, single-minded pursuit of the Anglo-Saxon race-"the mere creation of wealth." ${ }^{14}$ By this point, McCord had turned his attention to collecting, to the building of a National Museum.

At the same time that McCord's collecting had a cultural dimension, it was also very much the manifestation of his psychology Theorizing on the psychological makeup of the collector, psychologist Werner Muensterberger likens collecting to the 
behaviour of addicts-as an alcoholic thirsts for another drink, or as a gambler longs to place a bet, "the objects' grip on their owner can be described and understood only in terms of an emotional experience that appears to demand a more or less perpetual supply." ${ }^{15}$ It is a behaviour, moreover, whose roots can be traced to a deep, inner insecurity, an insecurity that is eased only through the relentless pursuit of yet another object. Writes Muensterberger,

the collector, not unlike the religious believer, assigns power and value to these objects because their presence and possession seems to have a modifying-usually pleasuregiving-function in the owner's mental state. From this point of view objects of this kind serve as a powerful help in keeping anxiety or uncertainty under control. ${ }^{16}$

At a personal, psychological level, then, collecting may have eased McCord's anxiety and uncertainty; objects provided him with a physical, tangible connection to the past which he idealized as a time of rootedness, connection and community. Muensterberger also argues that collecting stems from the phallicnarcissistic drive to possess the biggest, most spectacular collection. ${ }^{17}$ Certainly McCord displayed symptoms of megalomania. His was a divine calling. Comparing himself to Jacob, he wrote,

The Lord also found me in a desert land, very desert historically, in the sense that no one had thought of saving the landmarks. $\mathrm{He}$ led me about (the whole land). $\mathrm{He}$ directed my steps...listened to my voice. "crying in the wilderness", with the happy result that more than a solid foundation has been made for a museum which will later in Canada take the place of your great historical museum in the dear old land. ${ }^{18}$

On another occasion he noted that the "historical work, to which I have dedicated my life is on a scale far exceeding anything else in Canada. In fact it is the most important work of the kind in the Empire. "19

From Temple Grove, the family home situated on a gentle rise of ground off Côte de Neiges Boulevard, above the city below the hill, McCord. cast his collector's net throughout Canada and across the Atlantic to Great. Britain. Soon every wall, every corner, every room and every table top of Temple Grove was swimming with paintings, prints, maps and objects relating to the history of Canada and the British Empire. Photographs of the interior of Temple Grove intimate a chaotic eclecticism. As "a suitable epitaph" for himself, McCord suggested, "Here lieth one who stole everything historical he could not buy, and bought everything historical he could not steal, and created more than any Canadian who preceded him." Nevertheless, consistent patterns do emerge in. McCord's collection: patterns of natural hierarchy, elitism, heroism and Christian piety, for example. ${ }^{2 l}$ But. the part of his collection I want now to focus on is that dealing with war, for it tells us much about the culture of Imperial Canada.

II

Much of the writing on the history of war in Canada has been of the "maps and chaps" kind, that is the history of tactics and troop movements, of confrontation and conflagration. When historians move beyond this focus it is to examine national politics, that is FrenchEnglish relations and the question of conscription, or to write the social history of the men and women who served. It is only very recently that historians have turned their attention to the idea of war. in a cultural sense, that is what Canadians felt and thought about war: in the abstract, how war was imagined and represented. Here the scholarship of Carl Berger, Carman Miller and Paul Maroney is important. ${ }^{22}$ In their respective work, all write that war enjoyed a positive image in Imperial Canada. War was a sport, indeed the ultimate sport; it was part: of the Christian civilizing mission; and it reversed the enervating tendencies of modernity. Splendid imperialism, Christian mission and the cult of martial vigour: all coalesced around the idea of war as beneficial, positive and necessary. McCord very much shared this ideal.

In fact, McCord earnestly believed. that war served a vital purpose, both at the individual and at the national level. Thus his Historical Notebooks, five volumes of thoughts, anecdotes and observations, burst with stories of military heroism, of brave men dying 
nobie deaths, their final thoughis of Queen and country. Military men, moreover, necessarily sired "sclid offspring" of "superior ancestry." ${ }^{23}$ Indeed, McCord iraced his family history to the Plains of Abraham, the cieience of Quebec the War of 1812, the Boer War and World War I. "Fwo nembers went into the Boer War, and one sleeps in the Veldt," he wrote "in in Great War] five Officers, all with McCord blood in them and all descendants of Wolfe's Officers, went to France and three of them sleep under the redeemed sod of that land." 24 Desperate to provide his bride, Letitia Chambers McCord, with a gencalogy appropriate to her new station in life as the wife of a McCord, he noted that she was related to one Captain Maunsell who scrved in the 35th Regiment at the Plains of Abraham. ${ }^{25}$ intinately related to individual rejuvenation on the battiefield was national rejuvenation. McCord wrote about war as a "stimulus to bring out valuable qualities, what may be losi by a perpetual peace. "26 And in another note he observed,

\section{War-its superior aspect entering a country. See Wolfe's letters after the attack of Rochefort-almost the necessity \& advantage of losing many lives-"a thousand men" he says-but save the national honour and elevate the national character. Ruskin-Ruskin speaks also of elevating effects of war. ${ }^{27}$}

So committed was McCord to the romantic ideal of war that he even renovated the Temple Grove landscape to resemble the Plains of Abraham: the forty yards between the terrace and the road representing the distance between the two armies, the height of the terrace above the lawn representing Montcalm's advantage over Wolfe, and the twelve steps in the path leading to the house representing the twelve regiments of Wolfe's army. "Now listen," McCord instructed a visiting journalist, "can't you hear the conquering volley of that gallant British Army ringing down through the centuries? Can't you see the gallant Britisn Army rushing the position of the equally gallant French?"28

Not surprisingly, the romantic ideal of war simultaneously informed and found expression in McCord's collection. Describing himself as the "Humble door-keeper of the Canadian Valhalla," 29
McCord collected thousands of objects from the Plains of Abraham, the Defence of Quebec, the War of 1812 , the Rebellions of 1837, the North West Rebellions, tho Boer War and World War I. He repeatedly claimed that he possessed the world's largest collection of Wolfiana. At one point he likened his labours, the building of a national museum, to those of Woife: "But one thing is certain - Wolfe had to carry Quebec - and i must carry the museum. " ${ }^{30}$ Among other items in his possession were a lock of Wolfe's hair (for which he paid $£ 40$ in a 1914 Sotheby's auction), several letters bearing the General's signature, a silhouette of his mother and, most importantly, Wolfe's personal diary dated 18 June to 16 August 1759. Major-General Sir Isaac Brock also figured prominently as McCord acquired both Brock's red coat and his sword of honour. Another hero of the War of 1812 was Laura Secord whose cap made its way into McCord's collection, ${ }^{31}$ Charles Tupper, meanwhile, donated his son Gordon's "in case" letter.

If you are reading now, you will know that your youngest son "went under" proud as punch on the most glorious day of his life. I am taking my company over the top...

Dad-you can't imagine the wonderful feeling. A man thinks something like this, "well if I am going to die, this is worth it a thousand times." ...Mind you, I know what I am up against and that the odds are against me..$^{32}$

Gordon Tupper was killed at Vimy Ridge. In making the donation to McCord, Charles Tupper acknowledged his son's "services to the Empire."

In its early years, from 1921 to 1936 , the year it was closed for financial reasons, the McCord National Museum displayed the history of Canada in a roughly chronological fashion, from the pre-contact period through to the early twentieth century. Its display of objects relating to war, and the printed guides accompanying the display, continued the imperial spirit. Moreover, the Museum conformed very closely to whai the military historian John Keegan terms the rhetoric of battle history. First, the display of objects and the printed guides expressed an "extreme uniformity of human behaviour." There existed no mention of desertion or dissent within the ranks. Second, there was "a ruthlessly stratified characterization." While the 
British always displayed nobility and honour in war, Pontiac, Chief of the Ottawa First Nation, employed the tactics of "treachery" in his attack on Fort Michilimacinac ${ }^{33}$ And during their occupation of Montreal, American soldiers performed an "indignity" upon a statue of King George III, chopping off its head and tossing it inio a well. ${ }^{34}$ However, both McCord and the McCord National Museum were very careful not to apply inis element of battle rhetoric to the Battle of the Plains of Abraham. ${ }^{35}$ Conscious not to incite animosity, the Museum noted that the French and the English fought with identical honour and courage. "The third room we designated "The Companions in Arms', "read an early description.

$[T]$ he intention being to consecrate it solely to relics of the two great Heroes, Wolfe and Montcalm, who fell on the same day at Quebec in the battle of the Plains of Abraham, both dying nobly in defence of the honour of their respective Kings and Countries. ${ }^{36}$

As the third element in Keegan's rhetoric of battle history, the Museum presented "a highly oversimplified depiction of human behaviour on the battlefield." Wolfe, Montcalm and Brock were all unambiguously heroic, dashing and gallant. And finaliy, the Museum offered "no explanation of what happened to the dead or wounded. " 37

To note that McCord subscribed to the cultural ideai of war as a positive force, that he amassed a vast collection of objects related to Canada's military history and that these objects were then displayed in a linear, uncritical manner, is to merely note the self-evident. What then did all of this mean? In his monumental study of the American memory, Michael Kammen argues that "traditions are commonly relied upon by those who possess the power to achieve an illusion of social consensus. Such people invoke the legitimacy of an artificially constructed past in order to buttress presentist assumptions and the authority of a regime. ${ }^{\text {"38 }}$ Certainly, David Ross McCord and the early McCord National Museum projected the illusion of historical consensus, but what authority did it, in effect, buttress? The work of historian George Mosse is suggestive. In his book Fallen Soldiers: Reshaping the Memory of the World Wars, Mosse studies what he identifies as the
Myth of the War Experience in European nations. Locating its origins in the French Revolution and the German Wars of Liberation against Napoleon, the Myth of the War Experience, as expressed in public commemurations and national propaganda, stressed glory rather than horror, and meaningful purpose rather than senseless tragedy.

The Myth of the War Experience was designed to mask war and to legitimize the war experience; it was meant to displace the reality of war. The memory of the war was refashioned into a sacred experience which provided the nation with a new depth of rcligious feeling, putting at its disposal ever-present saints and martyrs, places of worship, and a heritage to emulate. ${ }^{39}$

According to Mosse, this myth served the important function of mobilizing volunteers for citizen-armies: to die for one's country is both noble and right. Meanwhile, by "collecting, ordering, preserving, and displaying," museums construct meaning, confer authority and grant legitimacy. ${ }^{40}$ The McCord National Museum, in its handling of war, thus perpetuated the Myth of the War Experience in the Canadian contexi. It was a site for the construction of what, in our introduction, were termed comforting myths and familiar narratives-heroism, loyalty and noble sacrifice. None of this is to suggest that McCord was the lackey of a militaristic state or that his muscum peddled propaganda disguised as history. However it is important to note that while cuitural history musi not be written as the story of élite managed conspiracy, culture was (and is) not neutral. To naively disregard the power in, and of, culture is to miss the complexity of the past.

By the time McCord died in 1930, and by the time the McCord National Museum closed six years later, the Myth of the War Experience was already open to challenge and concomitant controversy. In the early 1920s, veterans in Windsor, Ontario, demanded that the Detroit Free Press be banned from Canada for having printed a story on the drunkenness of British soldiers. Later in the decade, Sir Arthur Currie took legal action against a Port Hope newspaper "because he believed that allegations about his conduct of the operations around Mons in November 1918 reflected badly upon 
the men who had served under him in the Canadian Corps. ${ }^{n+1}$

Remembering war is necessarily difficult: how to commemorate the memory of those who died serving their country without simultaneously legitimating war as an acceptable means of arbitration. Reconciliation, the Ottawa monument to Canada's post-1945 role as an international peacekeeper, neither celebrates nor romanticizes war. Rather, it serves as an important reminder of Canada's role in the grim realities of today's international arena. Nevertheless, the Myth of the War Experience has endured. Its resilience is awesome. Despite Canada's role as a peacekeeper, we quickly found ourselves a participant in the Gulf War. Although cuitural critics label. this the post-national age, ${ }^{42}$ the tendency to think in terms of post-this and post-that obscures continuity with the national age. As long as we insist thai war is a legitimate arbiter of dispute we will require the Myth of the War Experience: to die for one's country is both noble and right.

\section{Notes}

* I would like to thank Hans Möller, David Moormañ and the anonymous readers for their comments on an earlier version of this essay. 1 would especially like to thank Pamela Miller who first proposed the essay and whose thoughtiul comments clarified my argument. Of course, I am responsible for any errors of fact andof interpretation.

1. "Lord Byng of Vimy Headed Procession," Montreal Gazette, 14 October 1921, 6.

2. Initially, McCord had planned to give his collection to the Montreal museum, the Chateau Ramezay. Then he turned his sights on McGill. But because the negotiations were taking so long, and proving so frustrating, MicCord at one point considered donating his collection to either the City of Toronto or Winnipeg. It was only through the determined efforts of W.D. Lighthall and Charles Gould, McGill's Librarian, that an acceptable agreement was ever reached.

3. "McCord Treasures Being Transferred," Montreal Gazeite, 16 February 1921, 6. According to the Gazette, "the first article to be carried across the threshold of the museum was a copy of Holy Script. A bible belonging to Chatles I and given by him io Sir William Douglas of Kenhead-first Duke of Quecusberly."

4. Suffering from arteriosclerosis, and prone to fits of rage, McCord spent the final decade of his life institutionalized, puncruated only by occasional-and very violent-visits to
Temple Grove.

5. See Richard Virr, "Son of the Great Dominion: W.D. Lighthail and the Lighthall Papers," Fontanus 2 (1989): 103-109.

6. McCord Family Papers, McCord Museum of Canadian History, file no. 2052a, Opening 1921.

7. Michael Kammen, "History as Lightning Rod," Organization of American Historians Newsletter 23, 2 (May 1995): 1. See also "An Update on the Enola Gay," Organization of American Historians Newsletter 23, 3 (Augusi 1995): 3 .

8. The Senate of Canada, The Valour and the Horror: Report of the Standing Senate Committee on Social Affairs, Science and Technology, (Ottawa, 1993): 3. Sce also David I. Bercuson and S.F. Wise, eds., The Valour and the Horror Revisited (Montreal and Kingston: McGiil-Queen's, 1994).

9. George L. Mosse, Fallen Soldiers: Reshaping the Memory of the World Wars (Oxford: Oxford University Press, 1990): 6-7.

10. Upon taking over responsibility for MicCord's finances in 1922, W.D. Lighthall and his son, W.S. Lighthall, wader into a confusing morass of debts, credits ano morigages, hit 1929 W.D. Lighthall commented on McCord, precariously perched as he was just one rung above his creditors. "David always ran his Estate on debis and borrowed money, and the position was so threatening when we took it over from himself that it was practically insolvent, and a very slight attack by any one of his creditors would have precipitated it into the gurf." Quote in Donald Fyson and Brian Young, "Origins, Wealth, and Work," in Pamela Miller ế al., La Famille McCord: Une vicion passionnée/The McCord Family: A Passionate Vision (Montreal, 1992): 27.

Describing McCord in the 1920\%, Pamela Miller writes, "In the last years of his life, as he slipped in and out of lucidity, he realized that he had sacrificed almosi everything for his museum. He fretted that no renis were coming in, that his taxes were unpaid and his wife alone in Temple Grove with no money for coal for the approaching winter." "Conclusion," in Pamela Miller et al., 141.

11. Jurgen Habermas. Quote in Kevin Walsh, The Represenuation of the Fast: Museums ond heriage in the post-modern world (London: Routledge, 1992): 7.

12. P.J. Bowler, The Invention of Progress: The Victorians and the Past (Oxford: Blackwe!l, 1989): 3. See also Mark Girouard, The Return to Cametot: Chivairy and the English Gentleman (New Haven: Yaie University Press, 1981); and Charles Dellheim, The Face of the Pasi: The Preservation of the Niedieval Inheritance in Victorian England (Cambridge: Camoridge Uñiversity Press, 1982).

13. MCFP, Historical Notebooks, vol, 1, p. 1, c. early 1890 s.

14. MCFP, Historical Nolebooks, voi. 3, p. 300, c. iate 1890 s.

15. Werner Muensterberger, Collecting, An Unruly Passion: 
Psychological Perspectives (Princeton: Princeton University Press, 1994): 136.

16. Ibid., 9.

17. Ibid., 13.

18. DRM to Mrs. F.E. Austin-Leigh, 4 September 1919 , MCFP, file no. 5007, Arctic Exploration: Franklin, Sir John. McCord was requesting the donation of a portrait of John Franklin.

19. DRM to Mr. James Playfair, 10 July 1920 , MCFP, file no. 5287 .

20. MCFP, Historical Notebooks, vol. 5, inside cover, n.d., c. 1910 .

21. For example, McCord amassed an ethnographic and archaeological collection "remarkable for its scope and documentation." Yet, even through this aspect of his collection, he centred on hierarchy, what he perceived to be the admirable hierarchy of Native society. He repeatedly noted that the object in question had once belonged to a Chief or an Indian princess. As Moira McCaffrey observes, "Being a member of a dominant elite, McCord viewed class structure as imbedded in the natural progression of Canadian society. By invariably linking the objects he collected to chiefs, warriors and princesses, he could reinforce to the public not only the inviolate presence of class structure even in societies considered "primitive", but also increase his own influence by demonstrating his membership in this elite group." Moira T. McCaffrey, "Rononshonni-the Builder: McCord's Collection of Ethnographic Objects," in Pamela Miller et al. La Farnille McCord, 117, 107.

22. See Carl Berger, The Sense of Power: Studies in the Ideas of Canadian Imperialism, 1867-1914 (Toronto: University of Toronto Press, 1970); Carman Miller, Painting the Map Red: Canada and the South African War, 1899-1902 (Montreal and Kingston: McGill-Queen's Press and Canadian War Museum, 1993); Paul Maroney, "The Highlanders Stepped Forth as if on a Holiday Parade: Canadian Newspapers and British Imperial Wars, 1884-1907," unpublished paper, presented at IMPERLAL CANADA 1867-1917, University of Edinburgh, Scotland, May 5-7, 1995; and Paul Maroney, "It Has Cost Much, but it is Worth More: Cultural Images of War in Canada, 1884-1914," unpublished paper, presented at Canadian Historical Association ANNUAL MEETING, Université du Québec à Montréal, August 24-27, 1995.

23. MCFP, Historical Notebooks, vol. 3, p. 133, c. late 1890 s.

24. MCFP, file no. 2065, First Museum Arrangement, c. 1920.

25. Ibid. Heraldiry and genealogy, argues Mark Girouard, were very important to Victorian Britain's new middle class. Together they provided, albeit often invented, impressive family histories. This attitude is evident in McCord's efforts to provide his wife with a family history worthy of her marriage into one of Anglo-Quebec's elite families. See Mark Girouard, The Return to Camelot: Chivalry and the English
Gentleman (New Haven: Yale University Press, 1981): 40. 26. MCFP, Historical Notebooks, vol. 3, p. 44, c. late 1890 s.

27. MCFP, Historical Notebooks, vol. 2, p. 286 , c. mid 1890s. This was a widely-held belief within the British Empire. "Take away honour, take away imagination from war, and it becomes carnage," Field Marshall Sir Evelyn Wood wrote. "War is always grievous, often terrible, but there is something worse, and that is the decline of enthusiasm of manliness, of the spirit of self-sacrifice. Peace is blessed, and if the price to be paid for is, that wealth accumulates and men decay, then the bloodiest wars are lesser evils." Field Marshall Sir Evelyn Wood to DRM, December 1909, MCFP, file no. 2058, First Museum Arrangement.

In a letter to W.D. Lighthall, K.L. Macpherson agreed that war was a terrible thing but went on to add: "Do you know, though, I think the men who get through this war will be very much more cultivated and interesting then they would have been if nothing had occurred. Everyone was getting too provincial and fond of money and comfort." Lighthall Papers, NAC MG 29 D 93, vol. 1, fille 1, 31 March [1915?].

28. C. Lintern Sibley, "An Archipelago of Memories," Maclean's 27 (March 1914): 7-8.

29. MCFP, Historical Notebooks, vol. 5, inside cover, n.d., c. 1910.

30. DRM to W.D. Lighthall, 13 December 1909, Lighthall Papers, NAC MG 29 D 93, vol. 1, file 28.

31. For an excellent discussion of Laura Secord as a symbol see Ceciila Morgan, "Of Slender Frame and Delicate Appearance: the Placing of Laura Secord in the Narratives of Canadian Loyalist History," Journal of the Canadian Historical Association 5 (1994): 195-212.

32. McCord Museum of Canadian History, accession no. M1393.

33. "Guide to Special Exhibit, C Room. Life in Canada, 1770-1870," MCFP, box Museum, Early Room Guides, List of Contents, 1924; file Guide to "C" Room. It is important to nuance this argument. While the McCord National Museum talked of the treachery of Pontiac, McCord himself romantically idealized Native Peoples at the same time as he observed the cruelty of European warfare. Still, the degree to which the Museum display conformed to Keegan's rhetoric of battle history is striking.

34. Ibid.

35. In the bonne entente tradition, McCord wrote Lady Laurier, "Le musée que je ferai n'est pas un musée McGill, ni un musée protestant, et certainement pas un musée anglais. Chaque objet dans le musée sera designé et exprimé dans les deux langues...et j'enseigne les principes auxquels votre associé marital dans ce monde a dédié sa vie-l'union des deux races." DRM to Lady Laurier, 4 November 1919 , MCFP file no. 5245 .

36. "The David Ross McCord National Museum," MCFP, box Museum, Early Room Guides, List of Contents, 1924; 
file McCord Museum, List of Contents, 1924.

37. See John Keegan, The Face of Battle (London: Jonathon Cape, 1976): 39-40. In point of fact, Keegan's rhetoric of battle history contains five elements. However, one element, "the very abrupt, indeed quite discontinuous movement of the piece" applies neither to McCord nor the McCord National Museum.

38. Michael Kammen, Mystic Chords of Memory: The Transformation of Tradition in American Culture (New York: Alfred Knopf, 1991): 5.

39. Mosse, 7.

40. Linda Hutcheon, "The Post Always Rings Twice: The Postmodern and the Postcolonial, "Material Hisiony Review 41 (Spring 1995): 5.

41. Jonathan F. Vance, "Custodians of Memory: Great War Veterans and the Image of the Canadian Soldier, 1918-1939," unpublished paper, presented at Canadian Historical Association ANNUAL MEETING, Université du Québec à Montréal, August 24-27, 1995: 22.

42. Writes Anne McClintock, "the almost ritualistic ubiquity of 'post-' words in current culture (posi-colonialism, post-modernism, post-structuralism, post-cold war, posi-marxism, post-apartheid, post-Soviet, post-Ford, post-feminism, post-national, post-historic, even post-contemporary) signals, I believe, a widespread, epochal crisis in the idea of linear, historical progress. " McClintock, "The Angel of Progress: Pitfalls of the Term 'Post-Colonialism', " in Patrick Williams and Laura Chrisman, eds., Colonial Discourse and Post-Colonial Theory: A Reader (New York: Columbia University Press, 1994): 292. 